\title{
Pengaruh Penggunaan Media Sosial dan Pengetahuan Kewirausahaan terhadap Minat Mahasiswa untuk Berwirausaha Dibidang Teknologi
}

\author{
Bambang Satrionugroho ${ }^{1)}$; Sri Tomo ${ }^{2)}$ \\ ${ }^{1)}$ Program StudiSistem Informasi, STMIK Sinar Nusantara Surakarta \\ 2) Program Studi Informatika, STMIK Sinar Nusantara Surakarta \\ ${ }^{1)}$ bambangsn@sinus.ac.id; ${ }^{2)}$ szrie@sinus.ac.id
}

\begin{abstract}
Students in College are used social media for their various activities, and they have studied entrepreneurship in class. The purpose of this research was to determine the effect of using social media, and entrepreneurial knowledge on students' interest in entrepreneurs' technology, partially and simultaneously. This research was conducted a quantitative study. The population was 550 students with the total sample were 110 students of STMIK Sinar Nusantara in 2017-2019 which has been taken the Entrepreneurship class. In this study, data analysis method was used multiple linear regression analysis technique. The result was showed that the partial and simultaneous of using social media, and entrepreneurship knowledge has significant effect on students' intention in entrepreneurs at the STMIK Sinar Nusantara Surakarta.
\end{abstract}

Keywords : Social Media, Entrepreneurship Knowledge, Interest in Entrepreneurship

\section{PENDAHULUAN}

Kegiatan berwirausaha sudah bukan merupakan hal yang asing bagi mahasiswa di Indonesia sekarang ini. Namun demikian masih banyak mahasiswa yang masih belum berani secara langsung untuk memutuskan kegiatan wirausaha sebagai pilihan hidupnya setelah lulus kuliah atau menyelesaikan studinya di perguruan tinggi. Hal ini terjadi lebih sering karena pengaruh image atau citra di masyarakat, bahwa rangkaian kegiatan setelah seseorang menyelesaikan studinya di perguruan tinggi adalah mencari pekerjaan. Artinya menjadi seorang pegawai atau karyawan yang diharapkan sesuai dengan bidang yang telah dipelajarinya selama di bangku kuliah.

Dengan berkembangnya teknologi, segala aspek kehidupan manusia menjadi lebih mudah. Khususnya terhadap perkembangan internet dan dunia maya, membuat batasbatas wilayah ataupun negara semakin lebih transparan, dikarenakan setiap orang bisa mendapatkan informasi dan berkomunikasi langsung dengan pihak lain di seluruh dunia dalam waktu yang bersamaan. Termasuk dengan berkembangnya media sosial berbasis internet, seperti facebook, whatsapp, instagram, youtube dan lain-lain.

Mahasiswa sebagai bagian generasi muda, tentunya sudah sangat akrab dengan kegiatan yang menggunakan internet termasuk media sosial. Bahkan ada orangorang yang setiap hari menghabiskan waktunya lebih banyak dengan berinteraksi di media sosial.

Mengacu pada penelitian yang dilakukan penulis sendiri sebelumnya, menemukan bahwa Materi pembelajaran Kewirausahaan memiliki pengaruh yang cukup siginifikan terhadap Minat Mahasiswa untuk berwirausaha. Sehingga mahasiswa yang sudah mendapatkan matakuliah Kewirausahaan, ternyata juga dapat semakin meningkatkan minat mahasiswa untuk berwirausaha[1].

Penelitian yang dilakukan oleh Alfaruk (2016), menunjukkan bahwa Pemanfaatan Sosial Media, Motivasi dan Pengetahuan berpengaruh secara simultan dan signifikan terhadap minat berwirausaha pada mahasiswa [2].

Penelitian ini bertujuan untuk mengetahui sejauh mana penggunaan media sosial, dalam meningkatkan minat wirausaha mahasiswa dibidang teknologi, yang juga dikaitkan dengan pengetahuan mereka dalam kewirausahaan.

\section{TINJAUAN PUSTAKA}

Hermawan Kertajaya dalam New Wave Marketing mengatakan bahwa mahasiswa harus bisa memperluas jaringan untuk lebih bisa berkomunikasi dengan yang lain, khususnya dengan menggunakan internet. Dalam hal ini media sosial yang sering digunakan di lingkungan mahasiswa bisa menjadi terbosan untuk merubah pola pikir mereka dalam berwirausaha. Dikarenakan 
peran media sosial dalam meningkatkan kinerja dunia bisnis sudah semakin diakui. Sehingga akan meningkatkan minat mahasiswa untuk berwirausaha dengan kemudahan yang ditawarkan. [3]

Media sosial telah memicu optimisme tentang potensi manfaat sosial. [4] Penggunaan media sosial oleh pengusaha telah melampaui pemasaran dan sekarang digunakan dalam jaringan bisnis, pencarian informasi, dan crowdfunding untuk bisnis mereka. Hal ini menyebabkan dampak yang signifikan dengan peningkatan kinerja perusahaan dan peningkatan inovasi menjadi hasil yang penting. [5]

Entrepreneurship Education (EE) yang disesuaikan dengan kelompok sasaran tertentu dapat mengatasi masalah norma subjektif secara terpisah untuk mahasiswa bisnis dan mahasiswa sains dan teknik.Pendidikan kewirausahaan (EE) yang efektif untuk kelompok sasaran yang spesifik. [6]

Minat seseorang dalam berwirausaha juga dipengaruhi oleh pengetahuan mereka tentang berwirausaha. Seorang wirausahawan akan dianggap berhasil jika memiliki pengetahuan, kemampuan dan kemauan berwirausaha. Ditekankan pula oleh Alma, yang menyatakan bahwa bakat berwirausaha seseorang akan dapat bertambah dan berkembang seiring dengan bertambahnya pengetahuan berwirausaha. Sebab dengan bekal pengetahuan yang cukup, diharapkan mereka dapat menjalankan usahanya dengan baik [7].

\section{METODE PENELITIAN}

\section{A. Menyusun Kuesioner}

Kuesioner disusun untuk memperoleh data-data yang sesuai dengan tujuan penelitian. Kuisioner terdiri atas 2 (dua) bagian yaitu kuesioner untuk variabel independent dan kuesioner untuk variable dependen.

\section{B. Penyebaran Kuesioner guna pengambilan Data}

Setelah kuesioner disusun, selanjutnya dilakukan penyebaran untuk pengambilan data, penyebaran kuesioner dilakukan di Kampus STMIK Sinar Nusantara Surakarta, yang dibagi untuk 5 jurusan (MI, KA, TI-D3, SI dan TI-S1) serta dalam 3 Angkatan (2017, 2018, 2019).

\section{Pengujian Validitas dan Reliabilitas Data}

Setelah data diambil, dan dimasukkan ke lembar kerja. Sebagai persiapan awal pengolahan data, data-data tersebut dilakukan pengujian validitas dan reliabilitas.

\section{Pengujian Hipotesis}

Pengujian Hipotesis untuk digunakan untuk mengetahui hasil analisis kuantitatif terhadap hipotesis, apakah terbukti atau tidak. Dengan menggunakan metode Regresi Linier Berganda.

Dimana hipotesis dalam penelitian ini:

1. Terdapat pengaruh yang positif dan signifikan dari Penggunaan Media Sosial terhadap Meningkatnya Minat Mahasiswa untuk Berwirausaha dibidang Teknologi.

2. Terdapat pengaruh yang positif dan signifikan dari Pengetahuan Kewirausahaan terhadap meningkatnya Minat Mahasiswa untuk Berwirausaha dibidang Teknologi.

3. Terdapat pengaruh yang posifit dan signifikan dari Penggunaan Media Sosial dan Pengetahuan Kewirausahaan, secara bersama-sama terhadap meningkatnya Minat Mahasiswa untuk berwirausaha dibidang Teknologi.

\section{HASIL DAN PEMBAHASAN}

\section{A. Hasil Kuesioner}

Penelitian ini menggunakan kuesioner yang mengidentifikasi 3 variabel bebas dan satu variabel terikat, dengan spesifikasi pertanyaan terkait dengan : Penggunaan Media Sosial sebagai sarana komunikasi dan wirausaha, adakah Motivasi mahasiswa untuk Berwirausaha, dan sejauh mana Pengetahuan mereka mengenai Kewirausahaan.

Sedangkan untuk Variabel Terikat, pertanyaannya terkait dengan Minat atau ketertarikan Mahasiswa untuk Berwirausaha, baik sebelum lulus kuliah maupun setelah Iulus kuliah.

\section{B. Pengolahan Data}

a) Data Responden

Pemetaan Responden pada Tabel 1 berikut adalah Mahasiswa STMIK Sinar Nusantara, dengan jumlah sampel sebanyak 110 orang. Terdiri dari 76 mahasiswa dan 34 mahasiswi.

Tabel 1. Data Kuesioner

\begin{tabular}{|l|l|l|l|}
\hline Keterangan & Pilihan & Jml & $\%$ \\
\hline JenisKelamin & -Laki-laki & 76 & 69.1 \\
& -Perempuan & 34 & 30.9 \\
\hline
\end{tabular}




\begin{tabular}{|l|l|l|l|}
\hline Keterangan & Pilihan & Jml & $\%$ \\
\hline Jurusan & - MI (D3) & 12 & 10.9 \\
& - KA (D3) & 10 & 9.1 \\
& - TI (D3) & 13 & 11.8. \\
& - SI (S1) & 28 & 25.5 \\
& - TI (S1) & 47 & 42.7 \\
\hline Angkatan & -2019 & 30 & 31.8 \\
& -2018 & 55 & 50.0 \\
& -2017 & 20 & 18.2 \\
\hline
\end{tabular}

Sumber: Data Responden

b) Data Deskriptif

Berdasarkan data pada tabel 1 terlihat bahwa dalam penelitian ini, Mahasiswa lakilaki berpartisipasi lebih banyak dibandingkan yang perempuan. Jumlah mahasiswa untuk jurusan strata satu jumlah sampel yang diambil lebih banyak dibandingkan mahasiswa D3. Dan dari segi angkatan masuk kuliah, dari angkatan 2018 merupakan mayoritas dengan $50 \%$, kemudian angkatan 2019 dengan $31.8 \%$ dan angkatan 2017 dengan 18.2\%.

c) Uji Statistik

1. Pengujian Validitas

Pengujian ini digunakan untuk mengukur sah atau tidaknya suatu kuesioner. Uji validitas dilakukan untuk memastikan masing-masing pertanyaan akan terklarifikasi pada variabel-variabel yang telah ditentukan (terlampir). Hasilnya seluruh item pertanyaan dinyatakan valid dengan korelasi [sig. (2tailed)] yang lebih kecil dari taraf signifikan ( $\alpha$ ) sebesar 0,05.

2. Pengujian Reliabilitas

Pengujian ini dilakukan dengan menghitung cronbach alpha dari masingmasing instrument dalam suatu variabel. Instrument yang dipakai dikatakan handal (reliable) jika memiliki nilai cronbach alpha lebih dari 0,6. Pengujian reliabilitas pada variabel Media Sosial, Motivasi dan Pengetahuan menunjukkan bahwa instrumen reliable karena memiliki cronbach alpha lebih dari 0,6 yaitu 0,611 (tabel 2). Maka hasil data kuesioner memiliki tingkat reliabilitas yang baik, atau dengan kata lain data hasil kuesioner dapat dipercaya. [8]

Tabel 2. Reliability Statistics

\begin{tabular}{|c|c|}
\hline Cronbach's Alpha & N of Items \\
\hline .611 & 3 \\
\hline
\end{tabular}

\section{Analisis Regresi}

Penelitian ini menggunakan analisis regresi linier berganda, untuk mengetahui bagaimana pengaruh variabel independen yaitu media sosial, motivasi wirausaha dan pengetahuan kewirausahaan terhadap variabel dependen Minat Wirausaha Mahasiswa.

\section{- Koefisien Determinasi}

Digunakan untuk menyatakan tingkat keterkaitan antara variabel independen yang dapat menerangkan variabel dependen, hal ini dapat dilihat dalam tabel 3.

Tabel 3. Model Summary

\begin{tabular}{|c|c|c|c|}
\hline Model & $R$ & $R$ Square & $\begin{array}{c}\text { Adjusted } \\
R \text { Square }\end{array}$ \\
\hline 1 & .536 & .287 & .274 \\
\hline
\end{tabular}

Berdasarkan tabel 3 tersebut terlihat bahwa ketiga variabel bebas, yaitu Media Sosial, Motivasi Wirausaha dan Pengetahuan Kewirausahaan memiliki pengaruh dan dapat menerangkan terhadap Minat Wirausaha Mahasiswa sebesar (R) 0,536. Jika dikuadratkan $\mathrm{R}^{2}$ tingkat determinasi / sumbangan efektif sebesar 0,287 (28,7\%) artinya kedua variabel bebas memiliki sumbangan efektif sebesar 28,7\% (dampak/ implikasi) terhadap variabel terikat, sedangkan sisanya sebesar $71,3 \%$ dipengaruhi oleh variabel lain yang tidak masuk dalam model. Untuk mengetahui apakah nilai $r$ hitung signifikan atau tidak, maka perlu dibandingkan dengan $r$ tabel atau dengan melihat probabilitasnya. Korelasi dikatakan signifikan, jika $r$ hitung lebih besar dari $r$ tabel ( $r$ hitung $>r$ tabel) atau nilai probabilitas kurang dari taraf kesalahan $(0,05)$. Terlihat probabilitasnya $0,000<$ taraf signifikansi 0,05. Hal ini menunjukkan korelasi/hubungan yang signifikan.

- Uji F

Tabel 4. ANOVA

\begin{tabular}{|l|l|l|l|l|l|}
\hline $\begin{array}{l}\text { Model } \\
1\end{array}$ & $\begin{array}{l}\text { Sum of } \\
\text { Suares }\end{array}$ & $\mathrm{df}$ & $\begin{array}{l}\text { Mean } \\
\text { Square }\end{array}$ & $\mathrm{F}$ & Sig. \\
\hline Regression & 13.889 & 2 & 6.944 & 21.53 & .000 \\
Residual & 34.511 & 107 & .323 & & \\
Total & 48.400 & 109 & & & \\
\hline
\end{tabular}




\section{Sumber: Olah Data SPSS}

Berdasarkan Tabel 4 diatas, nilai $F$ hitung sebesar 21,53 dengan signifikansi uji - $F=0,000$. Dimana nilai signifikansi uji yang lebih kecil dari alpha $(0,05)$ maka dapat disimpulkan bahwa variabel independen yang meliputi Penggunaan Media Sosial, dan Pengetahuan Kewirausahaan secara simultan atau bersama-sama berpengaruh signifikan terhadap Variabel Dependen yaitu Minat Wirausaha Mahasiswa. Yang artinya kedua variabel bebas tersebut secara bersama-sama dapat meningkatkan minat mahasiswa dalam melakukan kegiatan wirausaha dibidang teknologi atau menjadi seorang technopreneur.

Uji t

Tabel 5. Koefisien Variabel

\begin{tabular}{|l|c|c|c|c|c|}
\hline \multicolumn{1}{|c|}{ Model } & \multicolumn{2}{|c|}{$\begin{array}{c}\text { Unstandardiz } \\
\text { wd } \\
\text { Coefficients }\end{array}$} & $\begin{array}{c}\text { Stand } \\
\text { Coeff. }\end{array}$ & $\mathrm{t}$ & Sig. \\
\hline 1 & $\mathrm{~B}$ & $\begin{array}{c}\text { Std. } \\
\text { error }\end{array}$ & Beta & & \\
\hline (constant) & 1.5 & .319 & & 4.836 & .000 \\
Medsos & 43 & .071 & .358 & 4.277 & .000 \\
Pengetahua & .30 & .076 & .328 & 3.926 & .000 \\
$\mathrm{n}$ & 5 & & & & \\
& .29 & & & & \\
& 9 & & & & \\
\hline
\end{tabular}

Sumber: Olah Data SPSS

Berdasarkan hasil uji t pada Tabel 5 , dapat dilihat bahwa nilai signifikansi variabel Penggunaan Media Sosial sebesar 0,000 yang lebih kecil dari nilai alpha 0,05 , sehingga dapat disimpulkan bahwa Ho ditolak dan berarti terdapat pengaruh yang signifikan dari variabel bebas Media Sosial terhadap variabel terikat Minat Wirausaha Mahasiswa. Dimana nilai koefisien variabel ini sebesar 0,305 yang berarti memberikan pengaruh yang positif atau meningkat.

Dan berikutnya untuk variabel bebas Pengetahuan Kewirausahaan terlihat nilai signifikansi uji t sebesar 0,000 yang juga lebih kecil dari alpha 0,05. Sehingga dapat disimpulkan bahwa Ho ditolak dan berarti terdapat pengaruh yang signifikan dari variabel tersebut terhadap variabel terikat Minat Wirausaha Mahasiswa. Dan nilai koefisien sebesar 0,299 menunjukkan bahwa pengaruh tersebut positif meningkatkan minat wirausaha mahasiswa.

Model persamaan garis liniernya berbentuk : $Y=a+b 1 X 1+b 2 X 2$, dengan $Y$ adalah variabel terikat, dalam hal ini adalah Minat Wirausaha Mahasiswa, sedangkan $\mathrm{X} 1$ dan $\mathrm{X} 2$ adalah variabel independen, dalam hal ini adalah Penggunaan Media Sosial, dan Pengetahuan Kewirausahaan. Serta $a, b$ dan $\mathrm{c}$ adalah nilai konstanta dari masingmasing variabel.

Berdasarkan tabel diatas diketahui nilai constant-nya adalah 1,543 dan nilai pada variabel Media Sosial adalah 0,305 serta 0,299 untuk variabel Pengetahuan Kewirausahaan. Sehingga dapat diperoleh persamaan regresinya adalah sebagai berikut:

$$
Y=1,543+0,305 X 1+0,299 \times 2
$$

Dimana kedua variabel bebas, dilihat dari nilai koefisiennya memberikan pengaruh yang positif terhadap peningkatan minat mahasiswa STMIK Sinar Nusantara dalam berwirausaha. Dengan kontribusi dari variabel Penggunaan Media Sosial yang paling besar dibandingkan variabel Pengetahuan Kewirausahaan.

\section{PENUTUP}

\subsection{Kesimpulan}

bahwa:

Dari hasil penelitian ini dapat disimpulkan

1. Kedua variabel bebas yaitu: pemanfaatan media sosial dan pengetahuan kewirausahaan memiliki pengaruh yang signifikan terhadap peningkatan minat mahasiswa untuk berwirausaha pada STMIK Sinar Nusantara.

2. Terdapat pengaruh dari penggunaan media sosial terhadap minat berwirausaha pada mahasiswa STMIK Sinar Nusantara. Artinya dengan memanfaatkan media sosial yang lebih baik lagi, maka akan dapat meningkatkan minat mahasiswa untuk berwirausaha. Media sosial tidak hanya digunakan untuk berkomunikasi atau bertukar informasi semata.

3. Pengetahuan kewirausahaan yang dimiliki juga memiliki pengaruh terhadap Minat Wirausaha pada Mahasiswa STMIK Sinar Nusantara. Yang artinya semakin banyak mereka memiliki informasi ataupun pengetahuan tentang berwirausaha akan 
semakin meningkatkan minat mereka untuk terjun di kegiatan wirausaha.

\subsection{Saran}

Saran yang dapat disampaikan untuk penelitian dengan tema ini lebih lanjut adalah :

1. Menambahkan variabel yang lain dalam penelitian ini untuk meningkatkan level koefisien determinasi, yang dalam penelitian ini masih di tingkat 28,7\%. Masih lebih dari $70 \%$ dipengaruhi oleh variabel yang lain.

2. Mendapat pengetahuan kewirausahaan, tidak hanya melalui pembelajaran atau kuliah di kelas, namun bisa diperoleh dari berbagai sumber, baik online maupun seminar-seminar offline.

\section{DAFTAR PUSTAKA}

[1] B. Satrionugroho dan D. Nugroho, "Analisa Pengaruh Matakuliah Kewirausahaan Terhadap Minat Wirausaha Mahasiswa STMIK Sinar Nusantara", Jurnal IImiah Sinus, vol. 13, no. 1, pp. 1-12, 2015.

[2] M. H. Alfaruk, "Pengaruh Pemanfaatan Sosial Media, Motivasi, dan Pengetahuan terhadap Minat Berwirausaha pada Mahasiswa Ekonomi di Universitas Muhammadiyah Sidoarjo," J. Ekon. Pendidik. dan Kewirausahaan, vol. 4, no. 2, pp. 164172, 2016.

[3] H. Kertajaya, New Wave Marketing, 1st ed. Jakarta: Gramedia Pustaka Utama, 2013.

[4] H. Allcott, L. Braghieri, S. Eichmeyer, and M. Gentzkow, "The welfare effects of social media†," Am. Econ. Rev., vol. 110, no. 3, pp. 629-676, 2020, doi: 10.1257/aer.20190658.

[5] A. S. T. Olanrewaju, M. A. Hossain, N. Whiteside, and P. Mercieca, "Social media and entrepreneurship research: A literature review," Int. J. Inf. Manage., vol. 50, no. November 2018, pp. 90110 , 2020,

doi: 10.1016/j.ijinfomgt.2019.05.011.

[6] D. Maresch, R. Harms, N. Kailer, and B. Wimmer-Wurm, "The impact of entrepreneurship education on the entrepreneurial intention of students in science and engineering versus business studies university programs," Technol. Forecast. Soc. Change, vol.
104, 2015, doi: 10.1016/j.techfore.2015.11.006.

[7] B. Alma, Kewirausahaan untuk mahasiswa dan umum, Revisi. Bandung: Alfabeta, 2013.

[8] C. Trihendradi, Step By Step IBM SPSS 21: Analisis Data Statistik. Yogyakarta: Penerbit Andi, 2013. 